\title{
Analysis of Factors Affecting Organizational Effectiveness
}

\author{
Wenny Desty Febrian ${ }^{1}$ \\ \{wenny.sani27@ gmail.com ${ }^{1}$ \} \\ Management Department, Faculty of Bussiness and Social Science, University Of Dian \\ Nusantara, Tanjung Duren, West Jakarta, Indonesia ${ }^{1}$
}

\begin{abstract}
The research objective is that the Financing Company in Pekanbaru is a company engaged in financing that is distributed to the public in the form of credit or loan. This study examines how the influence of organizational characteristics, worker characteristics, environmental characteristics, management policies and practices, and leadership on organizational effectiveness in finance companies. The results of this study indicate that organizational characteristics have contributed to organizational effectiveness. The variables of environmental characteristics, worker characteristics and organizational and leadership characteristics have a significant contribution and effect on organizational effectiveness. Meanwhile, the variables of management policies and practices do not have a contribution to $\mathrm{Y}$ or have no significant effect on organizational effectiveness.
\end{abstract}

Keywords: Organizational characteristics, environmental characteristic , worker characteristic, practical policies and management, leadership and organizational effectiveness

\section{Introduction}

Within the organization there is management that cannot be separated from one another, constituting a unified system to realize the achievement of goals and objectives. The system in an organization is a totality set of parts for each other to achieve certain goals in the organizational environment. The more advanced an organization is, the more tasks it faces. Therefore, one way to deal with the many tasks associated with the growth and development of an organization is to communicate internally between leaders and subordinates in completing administrative tasks in order to achieve efficiency. A leader strives for harmony between the tasks/work carried out by one person / part with another person / part, so that it is hoped that confusion, inaccuracy and double work will not occur between one another. This means that work can be carried out efficiently and effectively. Financing companies are companies engaged in financing in the form of loans and loans, but do not collect savings from their customers, this is what distinguishes this finance company from banking. In this research, I tried to examine 10 existing finance companies. A finance company is a company engaged in financing, currently a finance company is a fast growing company. The finance is Adira Finance, FIF (Federal International Finance), BAF Bussan Auto Finance), SMS (Sinar Mitra Sepadan), BCA (Bank Central Asia) Finance, FIF (Federal International Finance), WOM (Wahana Ottomitra Multiartha) Tbk, BFI (BFI Finance Indonesia), BII (Bank International Indonesia) Finance, and BESS (Bentera Sinergis Multifinance). Next, I will describe the number of employees and the number of customers of the financing company above: 
Table 1. Number of Employees and Number of Customers for Financing Companies

\begin{tabular}{|c|c|c|c|c|}
\hline No & Name of Finance & $\begin{array}{l}\text { Employees } \\
\text { (People) }\end{array}$ & $\begin{array}{l}\text { Customers } \\
\text { (People) }\end{array}$ & $\begin{array}{l}\text { Persen- } \\
\text { tation } \\
(\%)\end{array}$ \\
\hline 1 & Adira Finance & 158 & 2033 & $20 \%$ \\
\hline 2 & FIF (federal international finance) & 142 & 1598 & $18 \%$ \\
\hline 3 & $\begin{array}{l}\text { WOM (Wahana Ottomitra Multiartha) } \\
\text { Tbk }\end{array}$ & 69 & 957 & $8 \%$ \\
\hline 4 & Summit Oto Finance & 63 & 993 & $8 \%$ \\
\hline 5 & BAF (Bussan Auto finance) & 76 & 1074 & $9 \%$ \\
\hline 6 & SMS (Sinar mitra sepadan) & 38 & 559 & $5 \%$ \\
\hline 7 & BCA Finance & 71 & 1772 & $9 \%$ \\
\hline 8 & BFI (BFI Finance Indonesia) & 84 & 1737 & $10 \%$ \\
\hline 9 & $\begin{array}{l}\text { BII (Bank International Indonesia) } \\
\text { Finance }\end{array}$ & 62 & 1108 & $8 \%$ \\
\hline 10 & $\begin{array}{l}\text { BESS (Bentera Sinergis Multifinance) } \\
\text { TOTAL }\end{array}$ & $\begin{array}{l}46 \\
809\end{array}$ & $\begin{array}{l}613 \\
12.444\end{array}$ & $\begin{array}{l}5 \% \\
100 \%\end{array}$ \\
\hline
\end{tabular}

Source: Finance Company

From the explanation above, it can be seen that some of the work plans have been completed slowly or have not reached $95 \%-100 \%$ at the specified time. From the table above, we can see the realization of the work plan that was achieved from the predetermined target, namely in 2016 it reached $73 \%$, and has increased every year until 2019 reaching $84 \%$. From the description of the above problems, the authors are interested in conducting further research on the effectiveness of the organization in finance, entitled: "Analysis of Factors Affecting Organizational Effectiveness".

Previous research that discussed organizational effectiveness was research made by Andri Joko Purnomo, a Diponegoro University Master of Management student in 2006, where the focus of the problem in this study was the low implementation of organizational effectiveness of the Batang Regency Fisheries and Maritime Affairs Office. Initial identification is due to the inability to reach regional retribution from fisheries and marine sector, which is an average of $65.68 \%$ during 2001-2005. The low implementation of organizational effectiveness is presumably influenced by factors of employee motivation, leadership and employee discipline. The result of the research is that the hypothesis Ho is rejected or Ha is accepted, which means that there is a harmonious relationship between the independent variables of employee motivation, leadership, and employee discipline with the dependent variable organizational effectiveness with a significance level of $95 \%$. Thus, it can be concluded that theoretically and empirically the three independent variables, namely employee motivation, leadership, and employee discipline, are the determining factors for the organizational effectiveness of the Batang Regency Fisheries and Marine Affairs Office. The similarity with this research is that it has one of the same research variables, namely the leadership variable, while the difference in this study uses 5 (five) variables, namely added with variables of organizational characteristics, environmental characteristics, worker characteristics and management policies and practices as well as different research sites [1].

Furthermore, Emirina, student of UIN Sultan Syarif Kasim Riau majoring in management, with the title Factors Affecting Organizational Effectiveness at PT Adira which was studied in 2011. simultaneously the four independent variables (organizational characteristics, environmental characteristics, worker characteristics and management policies 
and practices) jointly affect the effectiveness of the organization at PT. Adira as evidenced by the $F$ count of 13.246 with a significant value of $0.000<0.05$. The value of $R$ is 0.763 , which means that the relationship between the dependent variable and the independent variable is strong because $\mathrm{R}>0.5$. The value of Adjusted R Square is 0.538 , which means $53.8 \%$ of organizational characteristics, environmental characteristics, worker characteristics and management policies and practices affect organizational effectiveness at PT. Adira. The similarity with this research is that both have variable organizational characteristics, environmental characteristics, worker characteristics, and practice and management policies, as well as both researching at finance companies, while the difference is that this research adds leadership variables in the factors that affect effectiveness. organization, as well as the number of research sites this time are 10 (ten) finance companies, while in the previous study there was only one finance company [2].

Measuring the effectiveness requires: a) estimating the costs, the resources consumed the effort, in general, found in the literature as the input; b) estimating the results, or the outputs; c) comparing the two [3]. According to [4]The aim of this editorial in this issue of Journal of Physical Therapy (JPT) is to provide a detailed overview on the effects, efficacy, efficiency and effectiveness as four interrelated yet different terms in the field of Physical therapy (PT) and an analysis of the historical background with perspectives for the future. According to [5] One of the most important tasks in ensuring the effectiveness of controls in management systems is a thorough analysis of the processes and effectiveness of the entire management system, identifying the causes of deviations and discrepancies, establishing causal relationships in the system. Without knowledge and understanding of all these factors is impossible to solve the key management system tasks: assessment of processes and systems to identify the causes of such a state, and most importantly in this three-pronged problem, the formation of managerial decisions. According to [6] The growing development of organizations and their dominance over all aspects of human life is evident. People today need to do everything in the form of "organization" and organizations that are man-made and provide necessary facilities for the affairs of human life influence human behavior a lot. Therefore, it is necessary to investigate organizations and identify and solve the available problems so that the effectiveness can be improved. Meanwhile, [7] A proposed solution involves focusing beyond the mere number and extent of protected areas and suggests including their management effectiveness in the equation. The concept of managerial effectiveness has been a major concern for academicians and practitioners for several decades. This issue is, of course, important, for both public and private sectors in all economies but perhaps particularly so in developing economies where there is a desire to capitalize on strong economic growth opportunities [8]. An effective person is able to develop reasonable and stable basic strengths in life and has confidence in his ability to face and overcome life's challenges successfully. The definition of Thus, it appears that there are increasingly sophisticated practices in organizational management, focusing on relations between people which interact in the same organization, promoting team work, career development in an international context under the new economic challenges [9]. In general, performance problems and organizational management in banking are inevitable. Meanwhile, banking services play an important role in the economic development of a nation [10].

Organization is not a distant and impersonal phenomenon, it is intertwined in our daily lives, it is everywhere and affects us all. We are all members of organizational society (people who work in groups to achieve various goals). To be able to understand the definition of organizational effectiveness, we must first understand the meaning or definition of the organization. In providing the definition of organization, there are many who provide different opinions according to the views and interests of each, including [11] defines Organization, namely structuring and integrating (Itegranting) activities, namely the activities of people 
working together in interdependent relationships. Which means that the organization consists of:

a. Goal-oriented setting (people with goals)

b. Spikosocial system (people who interact in groups)

c. Technological systems (people who use knowledge and techniques)

d. Structured activity-activity interactions (people working together in patterned relationships).

Organizational Characteristics. Within the characteristics of the organization there are certain aspects that can affect effectiveness, including:

Organizational structure. According to [12] Organizational structure can be interpreted as the arrangement and relationships between parts and positions in the company. The organizational structure explains the division of work activities, and takes into account the relationship between these functions and activities to some extent. In addition to showing the level of specialization of these activities, the organizational structure also describes the hierarchy and structure of authority and reporting relationships. With the existence of an organizational structure, stability and organizational community remain.

Environmental Characteristics. According to [13] states that an organization must interact with its environment. The adaptation of the organization concerned through continuous interaction with its environment is very necessary. The continuity and ability to live of an organization is entirely dependent on its ability to adapt, make changes and react to its environment. The environment acts as a provider of energy resources, tools needed by the organization. The environment continues to cause changes and this results in the organization concerned must carry out a process of adjustment, the process must be dynamic and sensitive. The survival of any organization depends on the acceptance of the responsibilities demanded by the environment.

According to [14] defines that managers' interests in job satisfaction tend to center on the effects of employee performance. There are several satisfaction effects to assess this:

1. Satisfaction and productivity

2. Satisfaction and absenteeism

3. Satisfaction of the level of employee entry.

According to [15], the characteristics of workers are often referred to as individual characteristics (human nature), where human nature is different so that in an organization there is a need for cooperation in work. The characteristics of workers have different views of goals, needs and abilities in each individual. This individual has a direct influence on a sense of belonging to the organization and job performance. Without a sense of connectedness and achievement, effectiveness will be impossible.

Management Policies and Practices [16] argues that companies must be able to formulate policies that are able to accommodate differences, interests between individuals in the organization. The implication of the convergence of new human resource management is the existence of policy planning that focuses on the social responsibility of the organization and the conditions of internal employees. Management policies and practices are needed by an organization to achieve success through coordination planning so that activities can be directed towards the target.

The definition of a leader in a broad sense according to [17] which is published through the leadership web is a person who leads, by initiating social behavior by regulating, directing, organizing or controlling the efforts / efforts of others, or through prestige, power or position. In a limited sense, a leader is someone who guides, leads with the help of his persuasive qualities, and voluntary acceptance / acceptance by his followers. A leader is a person who has the authority to command others who are in their work to achieve organizational goals that need help from others. Apart from being a leader, he has an active role and always intervenes 
in all matters concerning the needs of his group members. Whereas leadership is the ability to influence others so that the person is passionately trying to achieve goals.

Effectiveness Approach. According to [18] as stated in the effectiveness approach web, there are three approaches to measuring organizational effectiveness, namely:

1. The resource approach, which measures the effectiveness of the input. The approach prioritizes the success of the organization in obtaining resources, both physical and nonphysical according to the needs of the organization.

2. The process approach is to see the extent to which the effectiveness of the program implementation of all internal process activities or organizational mechanisms.

3. The target approach (goals approach) where the focus is on the output, measuring the success of the organization to achieve the results (output) in accordance with the plan.

Organizational characteristics greatly affect organizational effectiveness because of how the structure within the organization and the technology that develops in the organization will support organizational effectiveness.

\section{Methods}

The author takes the research location on 10 (ten) finance in the city of Pekanbaru. Population is the whole of the object to be studied, while the sample is part of the population that we take to represent the population as a whole to be used as respondents in a study. The population in this study were all employees of finance companies in Pekanbaru, amounting to 809 people. And the sample result 100 people. The research used SPSS program.

\section{Result and Discussion}

Result research In this study, the sample amounted to 100 , then $\mathrm{df}=100-2=98$ with a value of $r$ table 0.165 . Reliability testing is used to determine the extent to which measurements can provide results that are relatively the same or not different (relatively consistent), when repeated measurements are performed on the same object. In this study the measurement used the Croanbach alpha technique. The measuring instrument can be said to be reliable if it has an alpha of more than 0.600 .

Explains that after the reliability test was carried out, the cronbach alpha value of each variable of organizational effectiveness, organizational characteristics, environmental characteristics, worker characteristics, management policies and practices, leadership and organizational effectiveness were $0.679,0.626,0.645,0.633,0.629$, and 0.676 which means that all of these variables are reliable with good decisions, because they have an alpha coefficient value above 0.600 .

This test aims to test whether the regression model found a correlation between independent variables (independent). A good regression model should not have a correlation between the independent variables. If the independent variables are correlated, these variables are not orthogonal. To detect multicollinearity, it can be seen from the Value Inflation Factor (VIF). If the VIF value > 10, multicollinearity occurs. Conversely, if VIF <10, multicollinearity does not occur.

Than, From the results of the data output, it is found that the value of all VIF values $<10$ means that there is no multicolonierity. And concluded that the multicolonierity test was fulfilled. 
To detect heteroscedasticity, you can see a scatterplot graph. The detection is by looking at the presence or absence of a certain pattern on the chart where the $\mathrm{X}$-axis is $\mathrm{Y}$ spreading above and below the 0 on the axis. As shown in the picture bellow :

Dependent Variable: REO

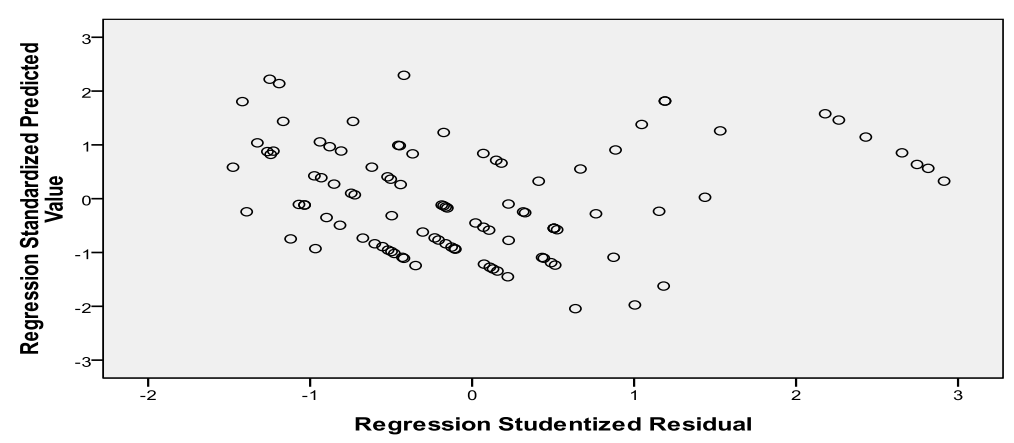

Figure 1. Diagram Scatterplot Heteroskedastisitas

In the figure, there is no clear pattern because the dots spread above and below the number 0 on the $\mathrm{Y}$ axis, so it can be said that in this regression model there is no symptom of heteroscedasticity. Normality detection is seen using the normal P-P Plot of Regression Standarized Residual graphs. In the picture, you can see the dots spread around the diagonal line and the spread follows the direction of the diagonal line. Then the regression model fulfills the normality assumption as shown in the figure.

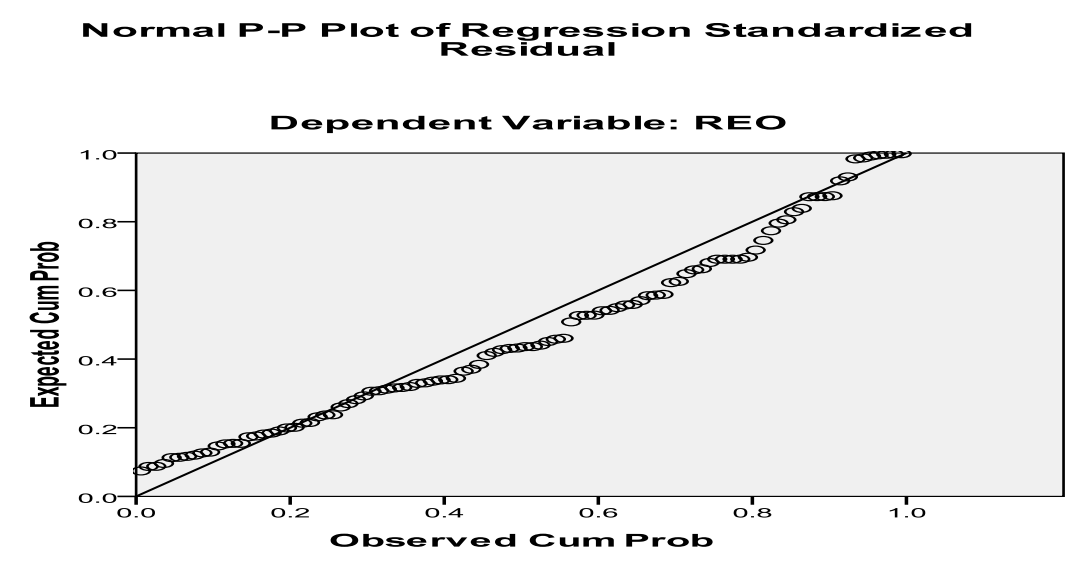

Figure 2. Diagram P-P Plot Normalitas

Table 2. Coefficientsa

\begin{tabular}{|c|c|c|c|c|}
\hline \multirow[b]{2}{*}{ Model } & \multicolumn{2}{|c|}{ Unstandardized Coefficients } & \multirow{2}{*}{$\begin{array}{l}\begin{array}{l}\text { Standardized } \\
\text { Coefficients }\end{array} \\
\text { Beta }\end{array}$} & \multirow[b]{2}{*}{ Sig. } \\
\hline & $\mathrm{B}$ & Std. Error & & \\
\hline
\end{tabular}




\begin{tabular}{lllllll}
\hline 1 & (Constant) & 3.417 & .684 & & 4.996 & .000 \\
& RKO & -.191 & .073 & -.242 & -2.605 & .011 \\
& RKL & .289 & .083 & .308 & 3.484 & .001 \\
& RKP & .318 & .118 & .257 & 2.701 & .008 \\
RKPM & -.106 & .094 & -.102 & -1.125 & .263 \\
& RK & -.317 & .093 & -.326 & -3.396 & .001 \\
\hline
\end{tabular}

The explanation of the test results above based on the regression equation is as follows:

1. Organizational characteristics (X1) Against organizational effectiveness (Y)

It can be seen that the sig value of the organizational characteristics is 0.011 . The sig value is smaller than the probability value of 0.05 , or the value of $0.011<0.05$. The variable X1 has a tcount of -2.605 with a t table of $-1,985$. So tcount <ttable can be concluded that the variable $\mathrm{X} 1$ has a contribution to $\mathrm{Y}$ or organizational characteristics (X1) have a significant effect on organizational effectiveness (Y).

2. Environmental characteristics (X2) Against organizational effectiveness (Y)

It can be seen that the sig value of environmental characteristics is 0.001 . The sig value is smaller than the probability value of 0.05 , or the value of $0.001<0.05$, then $\mathrm{H} 2$ is accepted and $\mathrm{Ho}$ is rejected. The environmental characteristic variable (X2) has a tcount of 3.484 with a t table of -1.985 . So it can be concluded that the environmental characteristics variable (X2) has a contribution to $\mathrm{Y}$ or has a significant effect on organizational effectiveness (Y).

3. Characteristics of workers (X3) Against organizational effectiveness (Y)

It can be seen that the sig value of the worker characteristics is 0.008 . The sig value is smaller than the probability value of 0.05 or the value of $0.008<0.05$, then $\mathrm{H} 3$ is accepted and $\mathrm{Ho}$ is rejected, so it can be concluded that the worker characteristics variable (X3) has a contribution to $\mathrm{Y}$ or has no significant effect on organizational effectiveness $(\mathrm{Y})$.

4. Management policies and practices (X4) on organizational effectiveness (Y)

It can be seen that the sig value of management policies and practices is 0.263 . The sig value is smaller than the probability value 0.05 , or the value $0.263>0.05$, so $\mathrm{H} 4$ is rejected and $\mathrm{Ho}$ is accepted. The variable $\mathrm{X} 4$ has a tcount of $-1,125$ with a ttable of $-1,985$. So tcount> ttable can be concluded that the variable management policy and practice (X4) does not have a contribution to $\mathrm{Y}$ or has no significant effect on organizational effectiveness $(\mathrm{Y})$.

5. Leadership (X5) Towards organizational effectiveness (Y)

It can be seen that the sig value for leadership is 0.001 . The sig value is smaller than the probability value of 0.05 , or the value of $0.001<0.05$, then $\mathrm{H} 5$ is accepted and Ho is rejected. The variable X5 has tcount, namely -3.396 with ttable -1.985 . So tcount <ttable it can be concluded that the leadership variable (X5) has a contribution to $\mathrm{Y}$ or has a significant effect on organizational effectiveness (Y).

The $t$ test is used to determine whether the independent variables partially have a significant effect on the dependent variable or not. The degree of significance used is 0.05 . If the significant value is less than the degree of confidence, then we accept the alternative hypothesis, which states that an independent variable partially affects the dependent variable. 
The explanation of the $\mathrm{T}$ test results based on the regression equation is as follows:

1. Organizational characteristics (X1) Against organizational effectiveness (Y)

It can be seen that the sig value of the organizational characteristics is 0.011 . The sig value is smaller than the probability value of 0.05 , or the value of $0.011<0.05$. The variable $\mathrm{X} 1$ has a tcount of -2.605 with a t table of $-1,985$. So tcount <ttable can be concluded that the variable $\mathrm{X} 1$ has a contribution to $\mathrm{Y}$ or organizational characteristics $(\mathrm{X} 1)$ have a significant effect on organizational effectiveness $(\mathrm{Y})$.

2. Environmental characteristics (X2) Against organizational effectiveness (Y)

It can be seen that the sig value of environmental characteristics is 0.001 . The sig value is smaller than the probability value of 0.05 , or the value of $0.001<0.05$, then $\mathrm{H} 2$ is accepted and Ho is rejected. The environmental characteristic variable (X2) has a tcount of 3.484 with a t table of -1.985 . So it can be concluded that the environmental characteristics variable (X2) has a contribution to $\mathrm{Y}$ or has a significant effect on organizational effectiveness (Y).

3. Characteristics of workers (X3) Against organizational effectiveness (Y)

It can be seen that the sig value of the worker characteristics is 0.008 . The sig value is smaller than the probability value of 0.05 or the value of $0.008<0.05$, then $\mathrm{H} 3$ is accepted and Ho is rejected, so it can be concluded that the worker characteristics variable (X3) has a contribution to $\mathrm{Y}$ or has a significant effect on organizational effectiveness $(\mathrm{Y})$.

4. Management policies and practices (X4) on organizational effectiveness (Y)

It can be seen that the sig value of management policies and practices is 0.263 . The sig value is smaller than the probability value 0.05 , or the value $0.263>0.05$, so $\mathrm{H} 4$ is rejected and Ho is accepted. The variable X4 has a tcount of $-1,125$ with a ttable of $-1,985$. So tcount $>$ ttable can be concluded that the variable management policy and practice (X4) does not have a contribution to $\mathrm{Y}$ or has no significant effect on organizational effectiveness (Y).

5. Leadership (X5) Towards organizational effectiveness (Y)

It can be seen that the sig value for leadership is 0.001 . The sig value is smaller than the probability value of 0.05 , or the value of $0.001<0.05$, then $\mathrm{H} 5$ is accepted and Ho is rejected. The variable X5 has tcount, namely -3.396 with ttable -1.985 .

So tcount <ttable it can be concluded that the leadership variable (X5) has a contribution to Y or has a significant effect on organizational effectiveness (Y).

Hypothesis Testing Results

So tcount <ttable it can be concluded that the leadership variable (X5) has a contribution to $\mathrm{Y}$ or has a significant effect on organizational effectiveness (Y).

Table 3. Hypothesis Testing Results

\begin{tabular}{|c|c|c|c|c|}
\hline Hipotesis & $\begin{array}{l}\text { variabele } \\
\text { thitungdanttable }\end{array}$ & $\begin{array}{l}\text { Vaue of Sig } \\
\text { and } \\
\text { Probability }\end{array}$ & Statement & Result \\
\hline $\begin{array}{l}\mathrm{H} 1 \\
\text { (X1 to } \mathrm{Y})\end{array}$ & $-2.605<-1.985$ & $0.011<0.050$ & $\begin{array}{l}\text { Variable RKO significant } \\
\text { to REO }\end{array}$ & $\begin{array}{l}\text { H1 received } \\
\text { H0 rejected }\end{array}$ \\
\hline $\begin{array}{l}\mathrm{H} 2 \\
(\mathrm{X} 2 \text { to } \mathrm{Y})\end{array}$ & $3.484>1.985$ & $0.001<0.050$ & $\begin{array}{l}\text { Variable RKL Significant } \\
\text { to REO }\end{array}$ & $\begin{array}{l}\mathrm{H} 2 \text { received } \\
\mathrm{H} 0 \text { rejected }\end{array}$ \\
\hline $\begin{array}{l}\mathrm{H} 3 \\
\text { (X3 to } \mathrm{Y})\end{array}$ & $2.701>1.985$ & $0.008<0.050$ & $\begin{array}{l}\text { Variable RKP Significant } \\
\text { to REO }\end{array}$ & $\begin{array}{l}\mathrm{H} 3 \text { received } \\
\mathrm{H} 0 \text { rejected }\end{array}$ \\
\hline $\begin{array}{l}\mathrm{H} 4 \\
\text { (X4 to } \mathrm{Y})\end{array}$ & $-1.125>-1.985$ & $0.263>0.050$ & $\begin{array}{l}\text { Variable RKPM Not } \\
\text { Sifnificant to REO }\end{array}$ & $\begin{array}{l}\mathrm{H} 4 \text { rejected } \\
\mathrm{H} 0 \text { received }\end{array}$ \\
\hline $\begin{array}{l}\mathrm{H} 5 \\
\text { (X5 to } \mathrm{Y})\end{array}$ & $-3.396<-1.985$ & $0.000<0.050$ & $\begin{array}{l}\text { Variable RK Significant to } \\
\text { REO }\end{array}$ & $\begin{array}{l}\text { H5 received } \\
\text { H0 rejected }\end{array}$ \\
\hline
\end{tabular}


The $\mathrm{F}$ test is used to determine whether the independent variables simultaneously have a significant effect on the dependent variable. This test is done by comparing the calculated $F$ value with the $\mathrm{F}$ table value, and the degree of confidence used is 0.05 . If the calculated $\mathrm{F}$ value is greater than the $\mathrm{F}$ value according to the table, then the alternative hypothesis, which states that all independent variables simultaneously have a significant effect on the dependent variable. $F$ value.

Table 4. ANOVAb

\begin{tabular}{|c|c|c|c|c|c|c|}
\hline & Model & $\begin{array}{c}\text { Sum of } \\
\text { Squares }\end{array}$ & Df & $\begin{array}{c}\text { Mean } \\
\text { Square }\end{array}$ & $\mathbf{F}$ & Sig. \\
\hline \multirow[t]{3}{*}{1} & Regression & 2.118 & 5 & .424 & 7.372 & $.000 \mathrm{a}$ \\
\hline & Residual & 5.400 & 94 & .057 & & \\
\hline & Total & 7.518 & 99 & & & \\
\hline
\end{tabular}

a. Predictors: (Constant), RK, RKL, RKPM, RKO, RKP

b. Dependent Variable: REO

Value of F hitung can see to the Tabel of ANOVA bellow : is accepted, meaning the variable organizational characteristics (X1), environmental characteristics (X2), employee characteristics (X3), management policies and practices (X4) and leadership (X5) as a whole / simultaneously have a significant influence on the organizational effectiveness variable $(\mathrm{Y})$.

\section{Conclusion}

Partially the results of this study can be explained as follows:

a. Organizational characteristics (X1) Against organizational effectiveness (Y)

It can be seen that the sig value of the organizational characteristics is 0.011 . The sig value is smaller than the probability value of 0.05 , or the value of $0.011<0.05$. The variable X1 has a tcount of -2.605 with a t table of $-1,985$. So tcount <ttable can be concluded that the variable $\mathrm{X} 1$ has a contribution to $\mathrm{Y}$ or organizational characteristics (X1) have a significant effect on organizational effectiveness (Y).

b. Environmental characteristics (X2) Against organizational effectiveness (Y)

It can be seen that the sig value of environmental characteristics is 0.001 . The sig value is smaller than the probability value of 0.05 , or the value of $0.001<0.05$, then $\mathrm{H} 2$ is accepted and Ho is rejected. The environmental characteristic variable (X2) has a tcount of 3.484 with a t table of -1.985 . So it can be concluded that the environmental characteristics variable (X2) has a contribution to $\mathrm{Y}$ or has a significant effect on organizational effectiveness (Y).

c. Worker Characteristics (X3) Against Organizational effectiveness (Y) It can be seen that the sig value of the worker characteristics is 0.008 . The sig value is smaller than the probability value of 0.05 or the value of $0.008<0.05$, then $\mathrm{H} 3$ is accepted and Ho is rejected, so it can be concluded that the worker characteristics variable (X3) has a contribution to $\mathrm{Y}$ or has a significant effect on organizational effectiveness (Y).

d. Management policies and practices (X4) on organizational effectiveness (Y) It can be seen that the sig value of management policies and practices is 0.263 . The sig value is smaller 
than the probability value 0.05 , or the value $0.263>0.05$, so $\mathrm{H} 4$ is rejected and $\mathrm{Ho}$ is accepted. The variable $\mathrm{X} 4$ has a tcount of $-1,125$ with a ttable of $-1,985$. So tcount $>$ ttable can be concluded that the variable management policy and practice (X4) has no contribution to $\mathrm{Y}$ or has no significant effect on organizational effectiveness (Y).

e. Leadership (X5) Towards organizational effectiveness (Y)

It can be seen that the sig value for leadership is 0.001 . The sig value is smaller than the probability value of 0.05 , or the value of $0.001<0.05$, then $\mathrm{H} 5$ is accepted and Ho is rejected. The variable X5 has tcount, namely -3.396 with ttable -1.985 . So tcount <ttable it can be concluded that the leadership variable (X5) has a contribution to $\mathrm{Y}$ or has a significant effect on organizational effectiveness (Y).

\section{References}

[1] Emirina, Factors Affecting Organizational Effectiveness at PT Adira. UIN Sultan Syarif Kasim Riau majoring in management, 2011.

[2] A. J. Purnomo and S. Sulandari, "BATANG," 2004.

[3] E. O. F. The, "E , e p p s," pp. 132-147, 2010.

[4] S. P. Kumar, "Effects, Efficacy, Efficiency and Effectivene in Physical Therapy - How Far Are We?," J. Phys. Ther., p. 98, 2018.

[5] Y. Vasilkov and L. Gushina, "Ludmila Gushina ANALYSIS OF THE EFFECTIVENESS AND EFFICIENCY OF MANAGEMENT SYSTEMS BASED ON SYSTEM ANALYSIS 3 . Methodology systematic," vol. 8, no. 3, pp. 347-356, 2014.

[6] V. KESHTKARAN, "Relationship between organizational effectiveness and the personnel managers' position of control in Shiraz University of Medical Sciences," J. Adv. Educ. Prof., p. 180, 2014.

[7] S. Stoll-Kleemann, "Evaluation of management effectiveness in protected areas:Methodologies and results," J. Basic Appl. Ecol., vol. 18, 2020.

[8] S. Zailani, “기사 (Article) 와 안내문 (Information) [,” Eletronic Libr., vol. 34, no. 1, pp. 1-5, 2015.

[9] G. Bucăţa, “THE CHALLENGES,” vol. XXIII, no. 4, pp. 275-281, 2018.

[10] Kurniawati, "Organizational management and employees performance in banking services," Аnnu. Appl. Sci. Eng. Conf., p. 66, 2018.

[11] \& R. Kast, Organisasi Dan Manajemen. Jakarta: Bumi Aksara, 2015.

[12] H. Umar, Metode Penelitian Bisnis. Bandung: Alfabeta, 2012.

[13] Winardi, Motivasi dan Pemotivasian dalam Manajemen. Bandung: Penduka Press, 2014.

[14] Steers, Antecedents and outcomes of organizational commitment. Jakarta: Administrative, 1977.

[15] M. Toha, Kepemimpinan Dalam Manajemen. Jakarta: Raja Grafindo, 2014.

[16] M. Bride, Belajar Sendiri Internet. Jakarta: Megapoint, 2017.

[17] H. P. Fairchild, Dictionary of Sociology. New Jersey: Littlefield, Adams \& Co, 2017.

[18] \& M. Lubis, Huseini, Teori Organisasi: Suatu Pendekatan Makro. Jakarta: Pusat Antar Universitas Ilmu Sosial, 2007. 